\title{
The trophy figure in the work of Giorgio De Chirico (and Piranesi)
}

\section{Bart Verschaffel}

\section{'en 1918, tout est fini'}

Giorgio De Chirico (1888-1978) ${ }^{1}$ owes his place in the history of modern art to a group of paintings completed between 1909 and 1919 that are known as the pittura metafisica. Having studied classical painting in Munich, De Chirico, first in Italy and from 1911 in Paris, created his distorted perspective depictions of empty town squares flanked by arcades and theatrical architecture, the level of the ground rising steeply to a high horizon, sparingly populated by isolated objects and figures, such as classical statues and trains, all painted in even colours with sharply defined shadows. From 1913 the statue of Ariadne appears, and odd and indescribable objects and signs find their way into these puzzling, yet still plausible, scenes. Picture planes start to overlap, or are stuck one onto another. This serves to break down the unity of place and scale in the overall image. Apollinaire attributes the originality of this part of De Chirico's art to his 'sense of the modern': 'the very fine and very modern intuitions of Mr. De Chirico are usually expressed in an architectural form. ${ }^{2}$ After several intense years in Paris, De Chirico returned to Italy in 1915 and there enriched his work with such new visual elements as the 'factory chimney', galleried towers and, especially, the 'tailor's dummy'. At the end of the war, André Breton and the Paris surrealists rediscovered De Chirico's work and interpreted it as an astonishing foreshadowing of their own project.

\section{Department of Architecture \& Urban Planning, Ghent University, Belgium}

Paul Guillaume organised De Chirico's first oneman show in Paris in 1922; however, with only a few exceptions, Guillaume showed only early work, and not what De Chirico was doing in the early 1920s. In the meantime, De Chirico had not succeeded in establishing a name for himself in Italy, and decided to go where he was successful, returning to Paris in 1924. There, it was as from death that he entered the surrealist world, which was full of admiration for his early work, but which could not appreciate his new work. This conflict turned into a rift when, in 1926, Breton execrated De Chirico in La Révolution surréaliste and established the image that was to dominate his further critical reception: after an initial prophetic 'metaphysical period', around 1919, De Chirico lost his brilliance and became a caricature of himself, creating only regressive and academic art. As Breton wrote: 'I have, we have spent five years now despairing of De Chirico, and admitting that he completely lost his sense about what he himself was working on ... If he had the nerves he would already long time have quit this game of ridiculizing his own talent. ${ }^{3}$ In the eyes of the art world, De Chirico remained an outsider for the rest of his life and was avoided as an unreliable and washed-up artist. In 1937 Paul Eluard wrote: 'Chirico has performed the miracle of painting "new landscapes" ... but in 1918, it was all over. ${ }^{4}$

The greatest obstacle to a proper understanding of the œuvre is that De Chirico himself accepted the 'Parisian' interpretation of his work. From the 
The trophy figure in the work of Giorgio De

Chirico (and Piranesi) Bart Verschaffel

Figure 1. Giorgio De Chirico, Le Voyage infini (1914).

Figure 2. Giorgio De Chirico, I/ Condottiero (1924-24).

Figure 3. Trophy of the Capitol, from

S. Reinach, Repertoire de Reliefs Grecs et Romains, 1, p. 311 , m. 69 .

Figure 4. G. Piranesi, Trofei de Daci (Ficacci, m. 718).
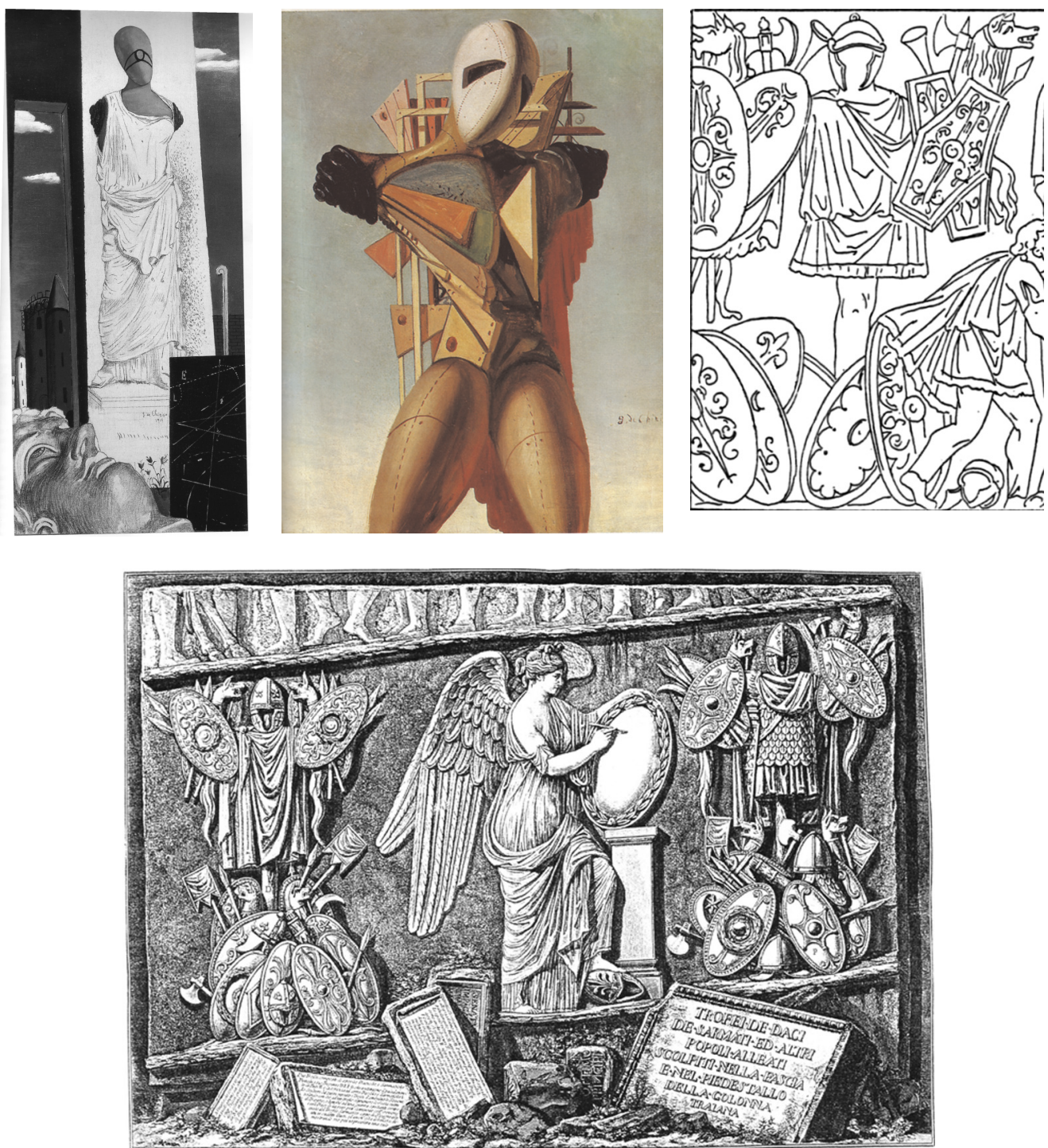
1920s he built up his œuvre and even retroactively reorganised it as if this interpretation were true. The reason is obvious: he could not himself reject the interpretation of his work to which he owed his reputation. Continuity between his early work, and his later 'unacceptable' work, would contradict the renown of his pittura metafisica as a miraculously early and precise formulation of modernism, and as the brilliant forerunner of the artistic avantgarde. The story of the œuvre, and the story of origins regarding the identity of the artist, are of course regulating principles. What an artist says of himself and his work should make it possible for him to situate himself and generate decisions that help move the œuvre forward; so, what he says does not by any means have to be true. But from the very beginning, in his autobiographical inventions and in his complicity in the myth of De Chirico as a proto-modernist, he himself went too far: it meant that he lost his grip on his own work.

\section{Pittura metafisica?}

The 'Parisian' interpretation is not correct. De Chirico undoubtedly aspired to capture his era (or the era to come) in images; but, he was not modern in the same way as Charles Baudelaire and Walter Benjamin. ${ }^{5}$ De Chirico was contemporary in the same sense as Nietzsche: like someone who-sucked down into the mud of history and ancient myths, ponderous words and meaningsdreams of lightness. The pittura metafisica, which certainly looks 'more modern' than De Chirico's early romantic revivals of Böcklin and Klinger, is linked entirely to the art exhibited in Munich while he was studying and to his later work. It is a matter of the personal and heroic artistic durcharbeiten of the myths and mythical conflicts that have accumulated in Western art and culture, and which, in the midst of the modern world, continue to speak of the 'eternal' in mankind.

The core of De Chirico's personal myth as an artist, before it was adapted to his 'Parisian' reputation as a proto-modernist, was that of the artistphilosopher whose images are born out of intuition and profound insights. De Chirico professed the classic romantic model of the tragic artist-poet-philosopher who, deeper and more receptive than the average mortal, suffers from the world and his times. De Chirico dictated that his œeuvre should commence at the magical moment when, reading Nietzsche during his first visit to Rome, he had a revelation: 'It was during a trip to Rome in October, after I had read the works of Friedrich Nietzsche, that I realised there are so many strange, unknown and extraordinary things that can be painted. ${ }^{6}{ }^{6}$ It is remarkable to see how this self-interpretation still stands, even in more recent literature. Schmied, for example, looks for all sorts of 'similarities' between De Chirico's œuvre and the German philosophers; and, at the end of his article, he quotes De Chirico as saying: 'the new artists are philosophers who transcend philosophy'. ${ }^{7}$ Baldacci states that De Chirico 'went beyond the traditional forms of Symbolism through the study of philosophy and literature'. ${ }^{8}$ Maurizio Fagiolo dell'Arco writes that 'De Chirico's basic culture is more philosophical than artistic'. $^{9}$

It is, naturally, always difficult, perhaps impossible, to determine precisely how creative processes work. All the same, it is more likely that images do 
The trophy figure in the work of Giorgio De

Chirico (and Piranesi) Bart Verschaffel

Figure 5. Giorgio De Chirico, II Condottiero (1918-19).

Figure 6. G. Piranesi, Trofei de Daci (Ficacc m. 718).

Figure 7. G. Piranesi, Trofei de Ottaviano Augusto (Ficacci m. 431).

Figure 8. Giorgio De Chirico, Les deux soeurs (1915).
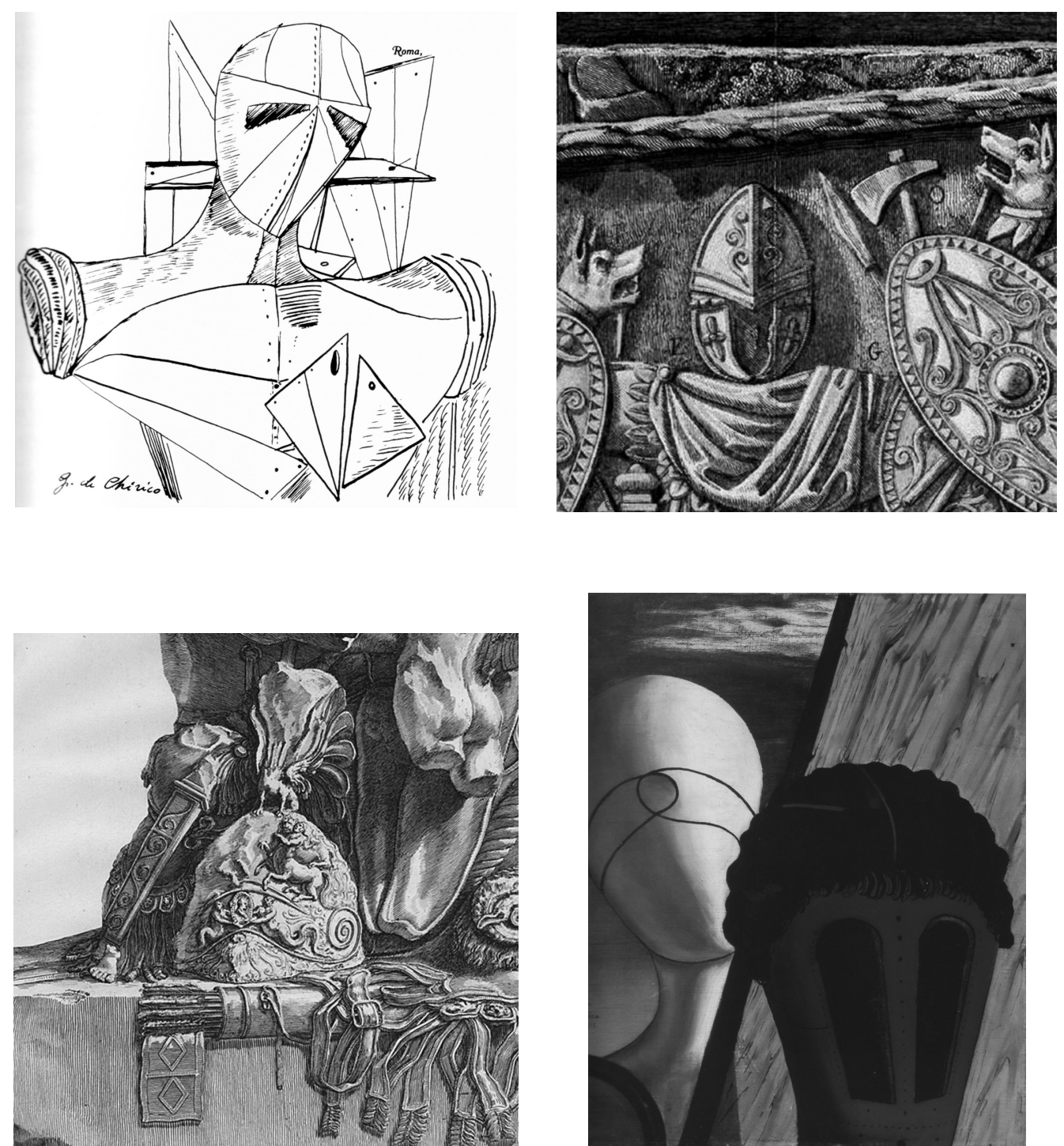
not arise out of philosophical insights, but rather by the variation and transformation of existing images. At this point, these transformations and variations may appear 'new' and unique because they have been uncoupled from their original setting. It seems as if an intuitive understanding or feeling has miraculously produced an image. De Chirico did what artists (and academics) have often done: he made abundant remote (and prestigious) references and at the same time held back the material on which his work is really based, and on which it depends, so that it appears to arise 'out of nowhere' ('from on high', as Paul Valéry would have said), and seems inexplicably 'new'. I am not claiming that thoughts and writings and reading cannot be important or decisive in artistic practice; but, images are also always tied to series of images and are variations of other images.

The suggestion that his images have philosophical origins, which De Chirico himself encouraged, is a diversion from the 'pictorial culture' on which they are actually based. When De Chirico joined his mother and brother, Andrea Savinio, in Milan in 1909, a period of intensive cooperation started that continued until 1911. The brothers composed music together, shared a studio and studied classical languages and primitive religions. Andrea was probably the more gifted of the two and, although younger, nevertheless made a name for himself sooner, as a composer. It seems that during this period Giorgio was often ill and depressed. However, De Chirico's genesis myth was not only a claim for the philosophically inspired origins of his work, but also dates the 'beginning' of his pittura metafisica to his trip to Rome in October, 1909. In this way he let his œuvre commence during the few weeks he spent alone, so that Andrea remained out of the picture. Gerd Roos's meticulous biographical reconstruction has, however, made it clear that the months spent with Andrea in Milan, and their cooperation, were extremely important to De Chirico, probably so decisive that he later felt it necessary never to mention this episode. It was not as a result of a miraculous revelation in Rome, or later in Florence, but in Milan, with his brother, that De Chirico gathered the raw material for the pittura metafisica.

\section{The manichino ...}

It was from 1914 that dolls made their appearance in De Chirico's œuvre. First as figures in classical white robes, with neither faces nor arms (Le voyage sans fin, Le tourment du poète and L'ennemi du poète from 1914), then as enlarged dolls wearing pieces of armour or roughly stitched garments (Le vaticinateur, 1914/15, Le duo, 1914/ 15), and lastly as jointed hollow figures made up of bits and pieces and slats and planks, heads either without a face or empty. This is the series that starts in 1917 with // trovatore, Ettore e Andromaca, Il condottiero, etc. The doll-like figure appears alone, sometimes with a female counterpart, and later in a duo with Andromaca's dressed in a peplos. Sitting in an interior, the dolls are the silent witnesses to a mysterious spectacle or view; when standing, they dominate the stage of an empty square like statues. The most imposing figure in this series-and at the same time one of De Chirico's most enigmatic creations-is the 1917 // grande metafisico: a tall, monumental, chaotic heap of 
Figure 9. Hero before a trophy, from S. Reinach, Repertoire de la Statuaire Grecque et Romaine, 1, p. 82.

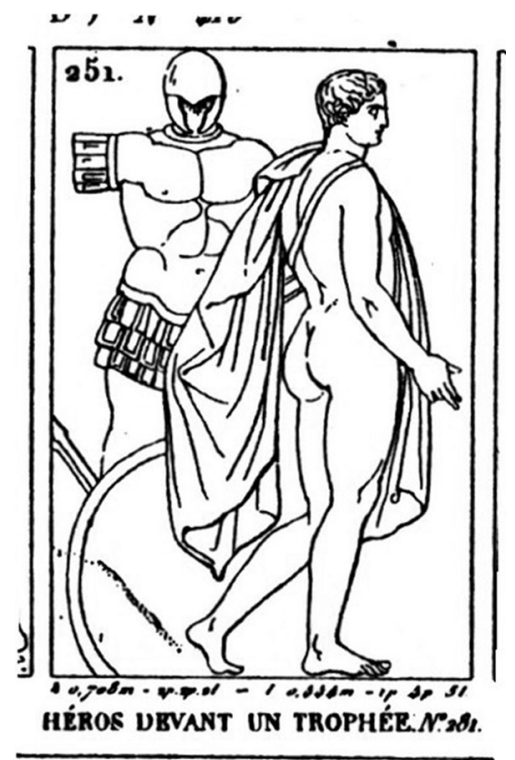

planks, sticks and indefinable debris and materials, from the top of which emerges a faceless doll's head, portrayed frontally, looking over an empty square. $^{10}$

From the very beginning, the doll figure played a key part in the interpretation of De Chirico as a proto-modernist. As early as 1919, Roberto Longhi discerned in the tailor's dummy the modern dehumanisation of the body: 'The unknown gods in the sacred display windows of the orthopaedists [...]; fixing the immortalisation of mankind on the dummy used by the drawing school and the tailor [...]; a horribly mutilated mankind, transformed into a dummy, appears shrieking and snarling on the vast, deserted stages of theatres. ${ }^{11}$ De Chirico's dolls are traditionally counted among the masses of masks, dolls, robots and poetic machines of the early avant-garde, from Dada and the Bauhaus to Expressionism and Surrealism. ${ }^{12}$ The doll stands for anonymity and loss of identity, for mechanisation and thingification, for the allure and fetishisation of goods, and so on. Following this line, literary-historical research has found the origin of De Chirico's doll in the motif of the 'faceless man' who appears in Apollinaire's work. ${ }^{13}$ This interpretation now seems accepted in the literature. In the catalogue of the most recent major De Chirico exhibition in 2007, Baldacci summarises it once again. He also refers to the Futurists' mechanical-dynamic figures and to Marinetti's poupées électriques. ${ }^{14}$ So there are many references and hypotheses, but they do have a common denominator: De Chirico's doll derives from the mannequin and signifies 'la vie moderne'.

At the same time, even those who offer these interpretations realise that other meanings are present. The stage on which De Chirico's dolls appear is certainly not the metropolis. The setting is less modern than tragic: the dolls stand like statues, or actors who suffer not from modern alienation, but from an old sore. As Baldacci himself indicates, the weakness of the accepted interpretations of the doll figures is that they are not specific enough: they do not take account of any details and say nothing about the appearance of these figures. 'But what are those metal cones that seal off the amputated shoulder, or those rubber-like cords that wrap around the ovoid head to disappear into a round hole in the centre?'15 Why are the heads hollow? Why do 


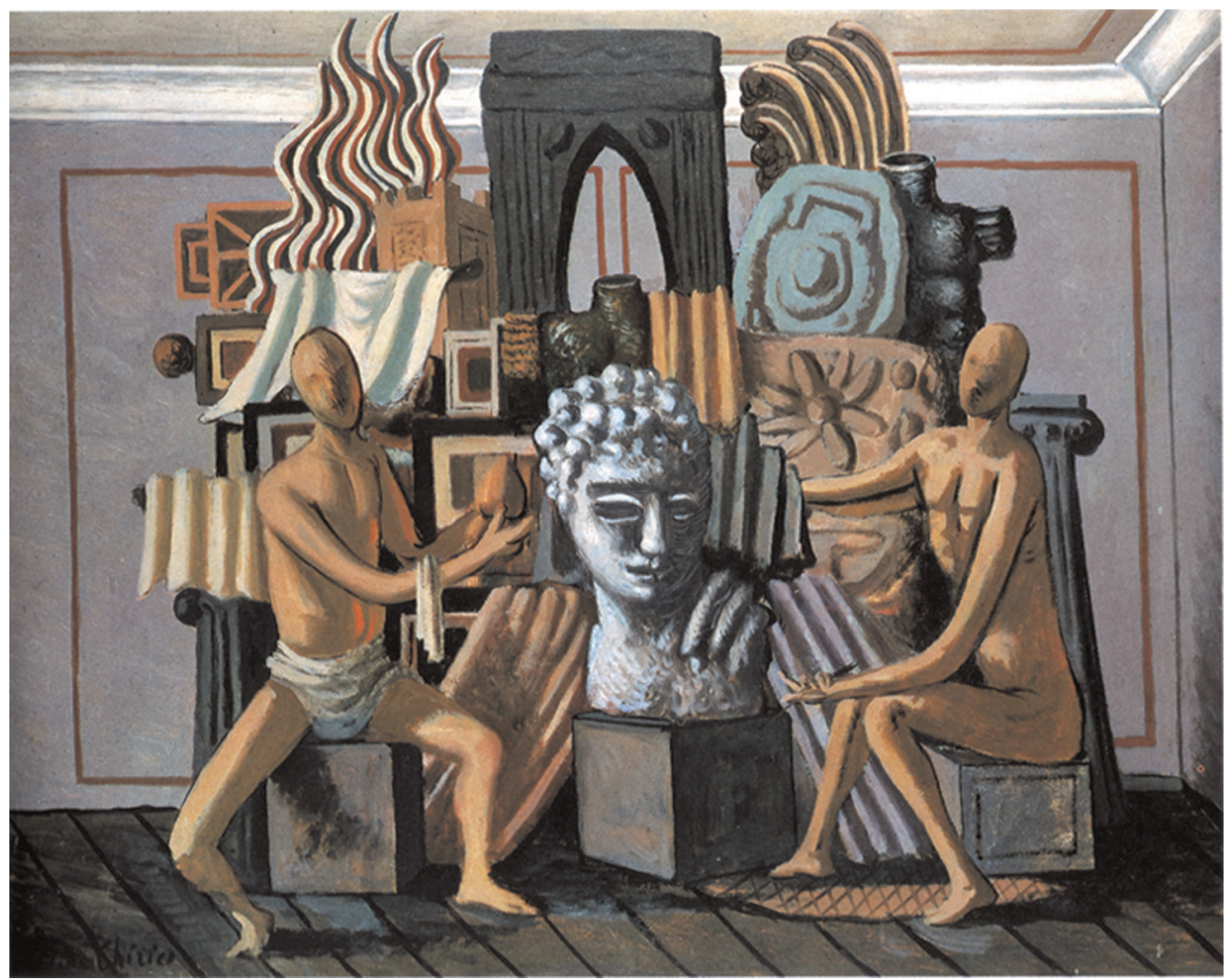

Figure 10. Giorgio De Chirico, Constructeurs de trophées (1928).

the figures have no limbs and from where do the knobs on the Trovatori's shoulders come? What is signified by the lines or threads stretched over these blind faces? My argument will be that De Chirico's 'mannequins' and 'great metaphysicians' do not merely resemble, but actually derive directly from, a classical type of sculpture-originally Greek—called the trophy.

\section{... as a trophy}

What does an archaic culture do when the fury and frenzy of battle is past and the battlefield is left scattered with dead warriors and bloody weapons? How is normality to be restored after the hysteria? How are the demons that had been unleashed to be calmed, and the souls of dead warriors to be prevented from returning? The battle- 
Figure 11. Nikè erecting a trophy (Museum of Fine Arts, Boston, USA).

Figure 12. Giorgio De Chirico, L'Ange juif (1916).

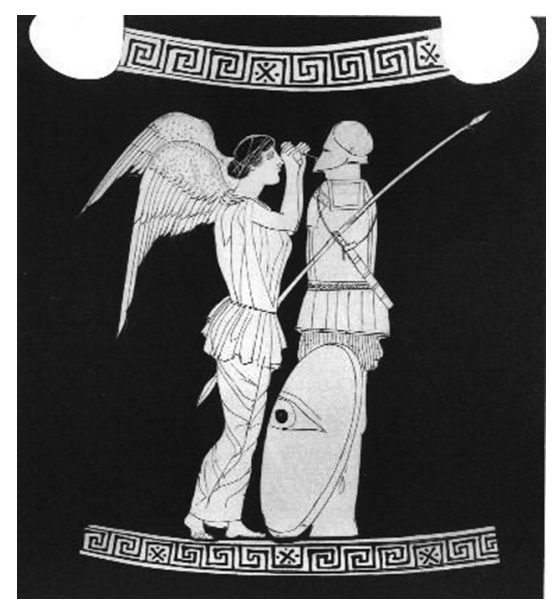

field, the dead bodies and the weapons of both friend and foe are now unclean and dangerous. One must certainly not take them away to use again or take them into the city; so, they are made unusable, sacrificed and left behind: broken into pieces, thrown in the water, burnt, hung from trees or from columns at the gates of the city. Even the enemy's bodies are mutilated or chopped into pieces so that the spirits of the dead cannot return and reuse them.

To this end, the Greeks erected a 'trophy' (or tropaion) on the battlefield where the conflict was decided. It comprised a stylised image of a warrior, without limbs, made from a pole with short transverse arms on which a torso was created using a breastplate; shields hung on the shoulders and an empty helmet was put in place as a head. The bloodied weapons were then thrown on a heap at the foot of this trophy, or rested against it, or were

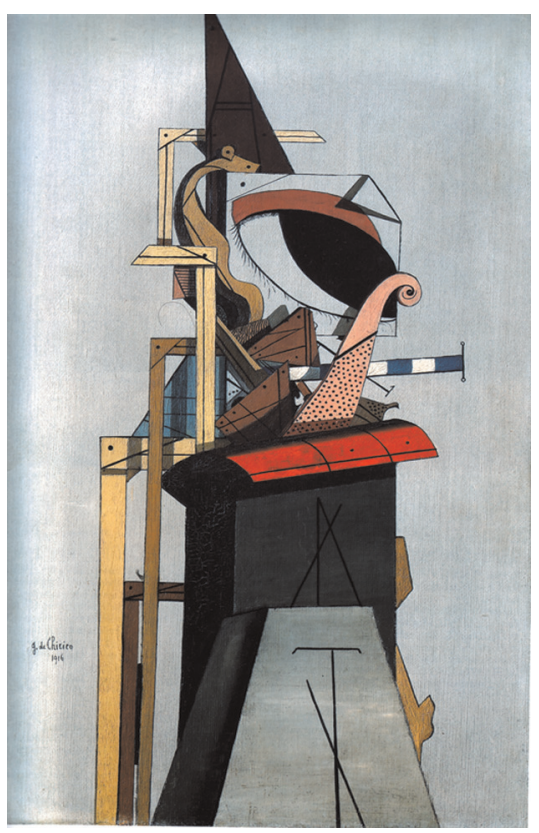

nailed to the pole. This trophy was then left to rot away, just like the memory of the battle. At the end of the classical period, this originally magical figure mutated into a sign of victory and commemoration, and a lasting monument was erected-on the battlefield or in the city itself-to immortalise the memory. In many cases it was a tower-like building in which the weapons were housed. In some cases, the 'warrior' was accompanied by the angelic figure of Nike, goddess of victory, who nailed the nameplate to the pole. The Romans adopted these Greek images and decorated the triumphal arches they erected in Rome with depictions 

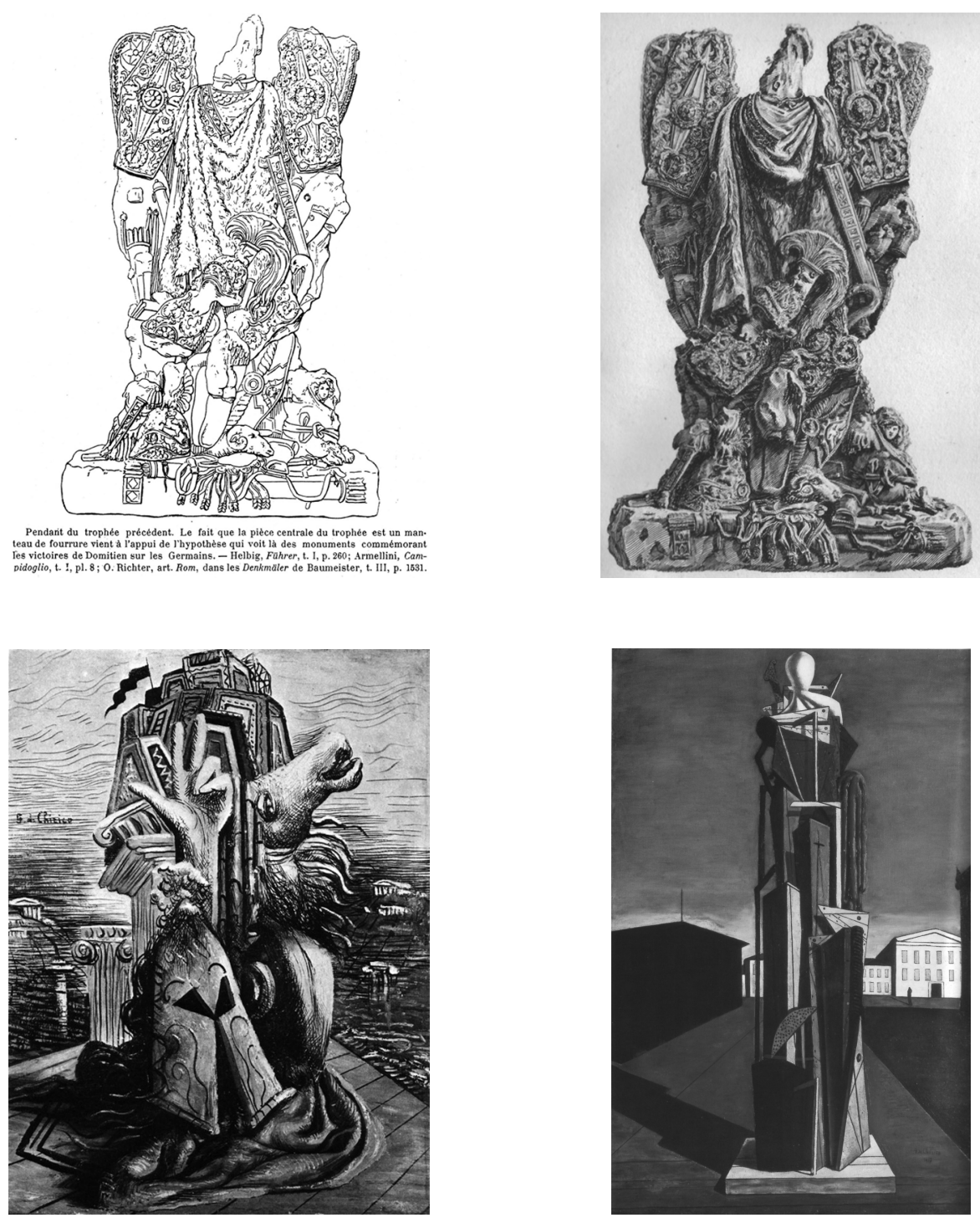

Figure 13. Trophy of the Capitol, from S. Reinach, Répertoire de Reliefs Grecs et Romains, 1, p. 290.

Figure 14. G. Piranesi, Trofei di Ottaviano Augusto (Ficacci 131).

Figure 15. Giorgio De Chirico, II Trofeo (1926).

Figure 16. Giorgio De Chirico, Grande Metafisico (1917).

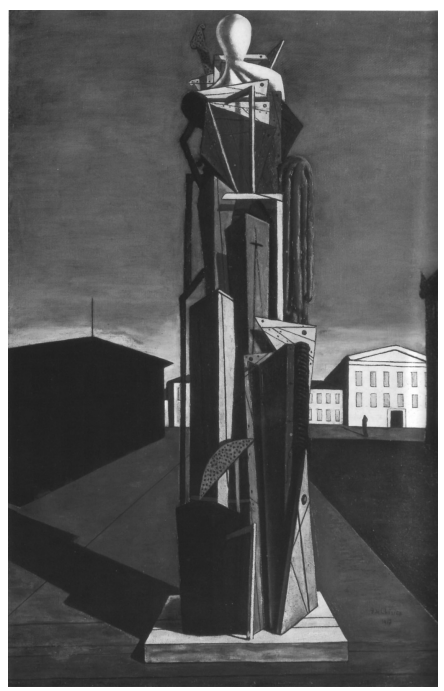


of trophies and of the triumphal parades in which primitive trophy figures were carried. ${ }^{16}$

\section{The 'trophy' in De Chirico's work}

In 1926, while in Paris, De Chirico explicitly gave the title 'Trophy' to a series of paintings and drawings. These artworks all feature a heap of weapons. ${ }^{17}$ In 1928 he depicted these heaps in interiors, each with a few of his gawky-looking gladiator figures, and called these works Constructeurs des Trophées. A striking passage in his 1929 novel Hebdomeros is devoted to these builders: 'When he entered this city, built like a citadel with inner courtyards and long geometrical gardens that assumed the rigid forms of bulwarks, he always found the same people there with the right proportions, completely healthy in body and mind and industriously engaged in their favourite activity: constructing trophies. Remarkable structures thus arose in the middle of drawing rooms and other places (both austere and amusing) much to the joy and delight of guests and children. Constructions that took on the shape of mountains ... ${ }^{18}$ In the literature on De Chirico the titles of these paintings have, remarkably enough, never been accepted as precise references. Baldacci detects in the 'Trophies' the influence of the neoclassical 'Greek-Egyptian-esoteric-Babylonian' decorative style. ${ }^{19}$

The only, very brief, reference to the classical trophy tradition of which I am aware, among studies on De Chirico, appeared in an entry on one of the trophy pictures in the catalogue of the last major exhibition; ${ }^{20}$ however, De Chirico knew very well the history and the exact meaning of the iconography. He cites the primitive trophy literally in several works, including the 1928 Constructeurs des Trophées. ${ }^{21}$ In two large works, La Vittoria from 1928 and Le Triomphe from 1928/9, he has his 'gladiators' carry the primitive trophy in a triumphal procession. In one of the decorative panels made for the collector Pierre Rosenberg in 1929, he makes a direct reference to the primitive trophy figures. ${ }^{22}$ There are also indications and irrefutable proof that he was already thoroughly aware of the tradition of the trophy before he referred to it explicitly in his titles. For this reason I am convinced that, not only the manichini, but also the majority of the pittura metafisica, developed out of the trophy tradition. $^{23}$

While training as a painter, De Chirico received a substantial introduction to the culture of antiquity. In 1906, after his studies at the Politecnico in Athens, he went to the Academy in Munich, the city known as 'the Athens of the North'. In 1909 he found himself in a 'joint venture' with his brother, in which antiquity was the main shared interest. The brothers studied Latin, classical cultures and archaeology, comparative mythology and primitive religions. Gerd Roos found a note written in 1910 or 1911 containing a list of authors comprising anthropologists, archaeologists and religious historians: Ernest Renan, Hermann Oldenberg, William Robertson Smith, Gaston Maspero, Wilhelm Mannhardt, Friedrich Nietzsche and Salomon Reinach. ${ }^{24}$ The reference to the religious historian and sociologist, Salomon Reinach, turns out to be especially relevant. Reinach was an erudite archaeologist who worked for the Louvre, where he gave very popular lectures, and was best known for his visual inventories of classical sculpture. He collected 
thousands of variants of sculptures and reliefs and arranged them typologically in small, simple line drawings under the title Répertoire de la Statuaire Grecque et Romaine and Répertoire de Reliefs Grecs et Romains. ${ }^{25}$ It is clear that Giorgio and Andrea used Reinach's inventory as a model book, almost to the point of plagiarism. ${ }^{26}$ There is the testimony of Fornari, one of De Chirico's assistants, who in 1926 quite exceptionally visited the master's studio and saw a catalogue of Reinach's lying open on a chair. He thought the book was being used by De Chirico's first wife Raissa, who was then studying archaeology, but as is evident from the list of authors from 1910/11, De Chirico knew of (and had used) Reinach's books much earlier.

In the literature, several examples have been published of sculptures taken by De Chirico from Reinach's catalogue, but the trophy figures are not yet mentioned. After all, the origin of the mannequin is invariably sought in the modern. Yet the visual similarities here already point in Reinach's direction. His catalogues mainly comprise an endless series of images the size of a postage stamp. By way of exception, however, the unusual and atypical (but well-known) Trophies of Marius, which Pope Sixtus $\checkmark$ moved from the Aqua Giulia to the balustrade of the Capitol, were illustrated in two fully elaborated drawings on two entire pages. ${ }^{27}$ Visual analogies are of course always open to dispute, but on the basis of the striking similarity of build to the figure and its position in front of the square, and also because of De Chirico's replication of specific individual elements, I assume that these trophies were the model for his 1926 series of trophies and for the figure appearing in / grande metafisico of 1917. In addition, the catalogue also includes a great many smaller illustrations and references to several variants of the trophy figure. Besides the aforementioned trophies on the Capitol, Reinach also devoted much attention to the triumphal columns of Aurelius and Trajan. Again on the basis of striking similarities, I assume that the dummy of the Trovatore type also derives from the ancient trophy figure, and probably from one of the scenes depicted on Trajan's column. It is, of course, very hard to verify the visual sources De Chirico had at his disposal, and equally difficult to know which elements he actually used.

Once their interest in a topic was aroused, De Chirico and/or Savinio more than likely amassed documentation, and Reinach richly illustrates this column. The similarities between De Chirico's characters and the trophy figures on Trajan's column are certainly striking. Like the primitive trophy, the Trovatore dolls are composed of empty torsos and pieces of protective gear; the typical but mysterious shoulder 'caps' are clearly the 'knobs' that have been cut from the two shields hanging from the trophy; the characteristic empty heads, with peculiar decorative lines, are transformed from the empty helmets that make up the trophy's 'head'; the lines take over from the edges or joins of the helmet; the doll figure as a slat construction is a transposition of the trophy hung with lances and shields. It is even possible that the first appearance of the faceless figure, still with a white peplos but already with its 'shoulder caps', derives from the trophy figures on the triumphal arch of Septimius Severus. ${ }^{28}$ There is, furthermore, the conspicuous motif of an 
isolated, large abstract 'eye', which appeared in several of De Chirico's works in 1916, including the intriguing, trophy-like construction in L'ange juif. ${ }^{29}$ Its similarity to one of the best-known Greek depictions of a trophy on a classical vase cannot be a mere coincidence: at the feet of a winged Nike, who is beating a name into the trophy, lies a shield on which the eye is painted. De Chirico had apparently adopted the copy and paste technique.

Besides the visual similarities to material with which we are certain De Chirico was familiar, there is some additional factual data too. It is always Reinach's catalogue that is referred to when it comes to interpreting De Chirico. However, apart from his archaeological and documentary work, Salomon Reinach also wrote general articles on art and on topics that combined archaeology, anthropology and religious history. ${ }^{30}$ Considering the authors the brothers used to read, and the wide range of interests this reveals, it is highly unlikely that Reinach's catalogue was the only work of his that they knew. Reinach himself wrote extensively on the subject of trophies in an article entitled Tarpeia in 1908, in which he refers, among other things, to the bas reliefs on the pedestal of Trajan's column. ${ }^{31}$ Even more interesting, though, is that during the period when De Chirico and Savinio were in Paris in 1913, Salomon's nephew Adolf Reinach (also an archaeologist and religious scholar) published prolifically on the subject, one example being the article Les Trophées et les origines religieuses de la guerre and another long general article on the trophy in the Dictionnaire des Antiquités. $^{32}$ The Reinachs were writing on a subject which, given the political circumstances, was clearly topical and attracted public interest.

Both Reinachs make a distinction between the anthropomorphic doll-trophy and the round and tower-shaped trophies, which consist of a 'holy tower', sometimes topped with a trophy figure, around which weapons are offered up. Adolf Reinach refers, in each case with a small illustration, to the tower of Pergamon, the Trophaeum Trajani in Cadiz and Augustus' trophy tower in La Turbie near Nice, amongst other examples. Once the importance of the trophy theme in De Chirico's work has been pointed out, the appearance of the tower motif in his work assumes a new significance. Some interpretations have tried to link the tower motif to De Chirico's supposed fascination for modernity, and thereby refer to the Mole Antonelliana: a spire-shaped tower with galleries built in Turin in the late nineteenth century. The first, square version of the tower in De Chirico's painting (La nostalgie de I'infini, 1912) is indeed highly reminiscent of the Mole, but the reuse of the motif in its round version (La grande tour and La torre, 1913) comes strikingly close to the typology of the trophy towers.

The question arises as to why De Chirico and/or Savinio was/were so attracted by the trophy as a subject that it was able to become one of the main themes in both their œuvres. When we look at personal circumstances, together with the historical context, we may find some clues. De Chirico developed his pittura metafisica in the years immediately prior to and during the First World War. He had chosen Italy as his native country, but his physical constitution and character did not enable him to act especially heroically. In 1911 he ignored his 
military call-up, took off to Paris and, in Italy, was condemned as a deserter. In 1912 he returned to enlist after all and was sent to Turin. He deserted once again, though, and wandered around for several days suffering from a full-blown existential crisis-just like Nietzsche-and then hid in Paris again. In 1915 he again joined up, but this time with protected status as a hospital soldier. In all this, a rather painful tension becomes apparent between the romantic-heroic aura of the artist with which De Chirico grew up, and the sort of heroism expected in wartime. What is a hero? What can an artist do in the course of history? One can understand that, in 1913 Paris, this deserter may have wanted to read about 'the religious origins of warfare', and developed an ambivalent interest in the figure of the dead hero (who is at the same time a symbol of victory), and that he painted melancholy gladiators until the end of his career. De Chirico's Trovatore does not, indeed, refer to the mannequin dummy of the avant-garde, but probably more to that other famous loser/hero of antiquity, also pictured in a sort of trophy arrangement, nailed to a cross ... De Chirico, the triumphant loser?

\section{‘. . Ie litografie del Piranesi sono addirittura insuperabile ... sorprendenti'}

It is beyond doubt that Reinach was a major pictorial source for both De Chirico and Savinio; however, it is highly unlikely that he would have been their only source, or even their main source. It is my view that the prints and publications of the Italian architect, archaeologist, collector and etcher Giovanni Battista Piranesi (1720-1778) were also an important source for De Chirico and Savinio, and possibly provided De Chirico with the basis for his work. Piranesi is best known for a series of large vedute di Roma, in which he glorifies the grandeur of Rome and its ruins, but he also did much purely creative work, such as the Grotteschi and the well-known Carceri; he, furthermore, published substantial books of architectural plates and writings on Rome. Remarkably, Piranesi remains utterly absent from the whole of the literature on De Chirico, even from the major exhibition 'On Classic Ground', staged in 1990. His name does not appear at all in the indices of names in the main catalogues and studies. I wish to argue that Piranesi, not only provided some of the visual models for De Chirico's trophy figures, but that his work also shaped the core of De Chirico's mythology of Rome. One thing this will make possible is a much more focused interpretation of the motif of the archeologi, which De Chirico developed from 1925.

It is said that De Chirico found the basic inspiration for his œuvre during his first trip to Rome, in 1909. The pittura metafisica does clearly refer, among other things, to the tomb of Cecilia Metella and the Porta San Sebastiano. In that period De Chirico also wrote about the mysterious nature of Roman walls and arcades. It is noteworthy that commentators accept the romantic notion that De Chirico did not discover Rome until he visited it, and that his work is the result of the powerful visual impression it made upon him during his first trip there, ${ }^{33}$ whereas, it goes without saying that a young artist with his education would have already seen thousands of pictures of Rome, without ever having visited the city. Like everyone else, De Chirico first learnt about Rome from books and illustrations. In his memoirs, 
Figure 17. Trophy tower (Efese/Ephesus), from G. Picard, Les Trophées Romains, p. 147.

Figure 18. Giorgio De Chirico, La grande torre (1913).

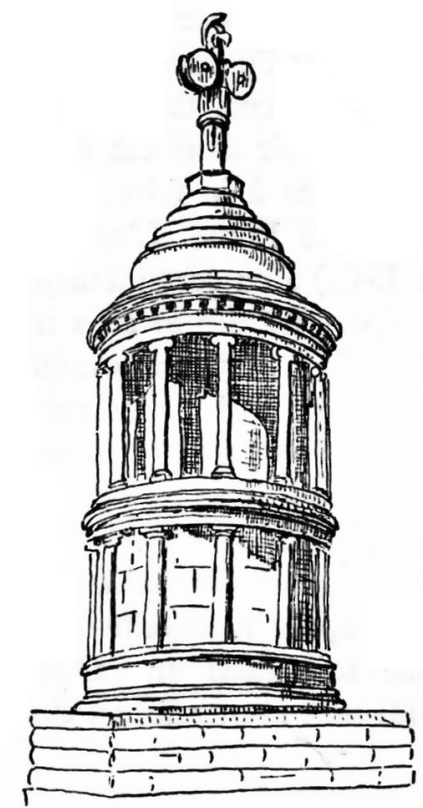

Trophée d'Ephèse, restitution de Niemann

De Chirico's fellow student, the painter Pikionis, writes that he spent hours with De Chirico looking at works by Klinger in the print room at Munich. The Graphische Sammlung that De Chirico visited was largely destroyed in the Second World War, but among its 300,000 prints there would certainly have been some by Piranesi. And we know that De Chirico learnt to etch there, taught by Peter Halm, who specialised in pictures of architecture and vedute. It is unlikely that Piranesi was never mentioned in the studio. ${ }^{34}$ In Milan, De Chirico studied Latin and archaeology with his brother Andrea

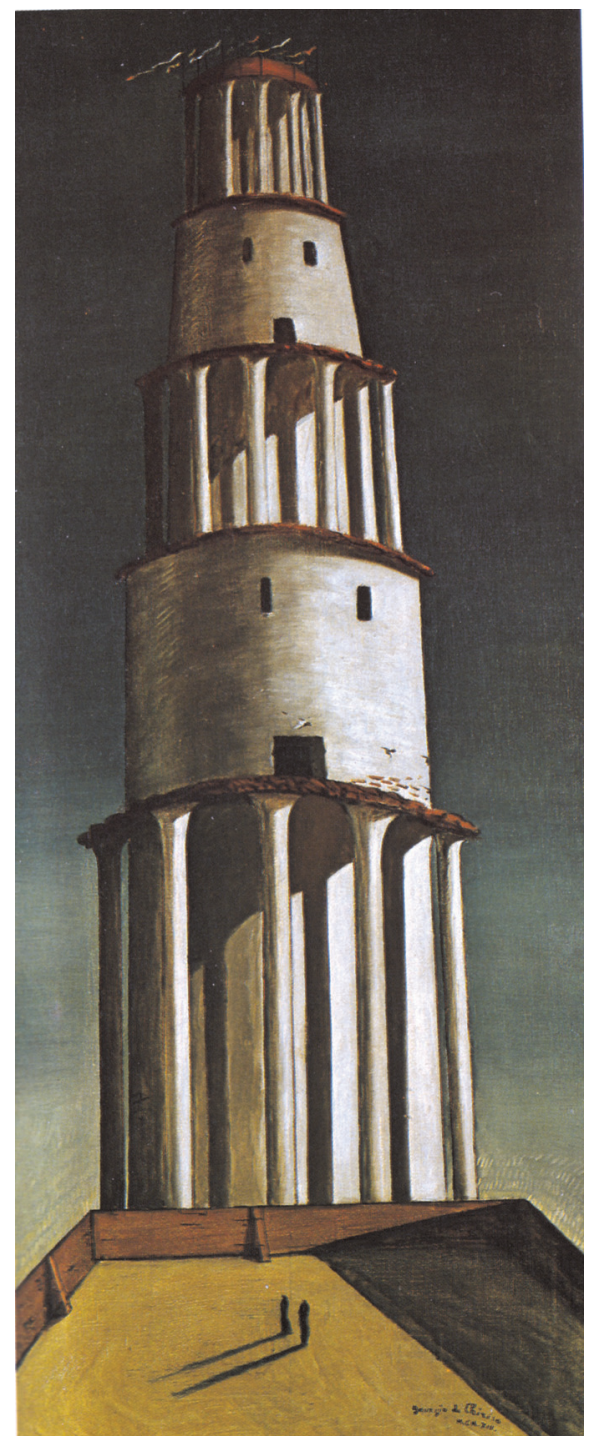


under Domenico Fava, a librarian at the Brera, who must also have been familiar with Piranesi's ideas and archaeological studies. ${ }^{35}$ And in the introduction to the pictures of Aurelius' Column, with two very important depictions of trophies, in the third volume of his Répertoire, Salomon Reinach refers explicitly to 'les grandes et belles planches de Piranèse'. ${ }^{36}$

In addition to these pointers there is also a revealing document that enables us to link Piranesi with De Chirico with certainty. It has until now escaped the attention of the critics. In the period after the First World War, De Chirico wrote art criticism in Italy. In 1920, for example, he reviewed three exhibitions for the Milanese periodical // Convegno under a monogram, including a Mostra Piranesi al Castello, which he praised highly. ${ }^{37}$ These were probably the prints from the Bertarelli collection, which is today still kept in the Castello Sforzesco. ${ }^{38}$ In any case, it appears from the review that it was a large exhibition: 'almost the complete works'. Two other elements are also important. First, De Chirico called Piranesi's work 'overfamiliar': 'there is no well-off household that does not have two prints on the wall, one each side of the clock', and other such comments. It is extremely unlikely that De Chirico would write anything like this if he had discovered Piranesi for the first time at this exhibition. Secondly, De Chirico writes as if he had not only seen works by Piranesi, but also read his writings. After all, as he observes, Piranesi was active 'not only artistically, but also theoretically':

We have two treatises on architecture by Piranesi in which he defends the total autonomy of Roman architecture and thereby rejects the historical argumentation whose intention it was to trace it back to Greek architecture. His impas- sioned alliance with Roman architecture monopolised the whole of his artistic activity: his only source of inspiration was the landscapes and ruins of Rome.

It is apparent from this passage that De Chiricoprobably together with all the archaeologists of the period-was familiar with Piranesi's archaeological and artistic views. In his reference to 'two architectural treatises', De Chirico either means the four volumes of the Antichità Romane (the definitive non-polemical work of archaeology) and Della Magnificenza ed Architettura de' Romani, or else the Magnificenza and several polemical writings including Osservazioni sopra la lettre de M. Mariette and Parere su l'Architettura. Piranesi was a protagonist in the debate about the respective independence and worth of Greek and Roman art and architecture. Piranesi defends the independence of Roman architecture against Winckelmann and Le Roy, and traces it back to the Etruscans and the Egyptians. In his view, the nobility of Roman architecture lies not in the beauty and purity of the architectural orders and proportions, but in the power and purposefulness of its buildings and in the freedom of its decoration. De Chirico refers explicitly to the theses Piranesi advances in the Parere and (or, rather, instead) refers to Piranesi's late-eclectic decorative works: 'So that ultimately he [Piranesi] only used the Roman antiquities to make new compositions and to provide a pattern or a subject for his imagination'. This last sentence expresses a sympathy that likely derives from a clear affinity with his own artistic strategy. It appears from De Chirico's comments that he writes of things one does not find out by merely looking at prints in an exhibition. My conclusion is that De Chirico was 
The trophy figure in the work of Giorgio De

Chirico (and Piranesi) Bart Verschaffel

Figure 19 Giorgio De Chirico, L'archeologo (1927).

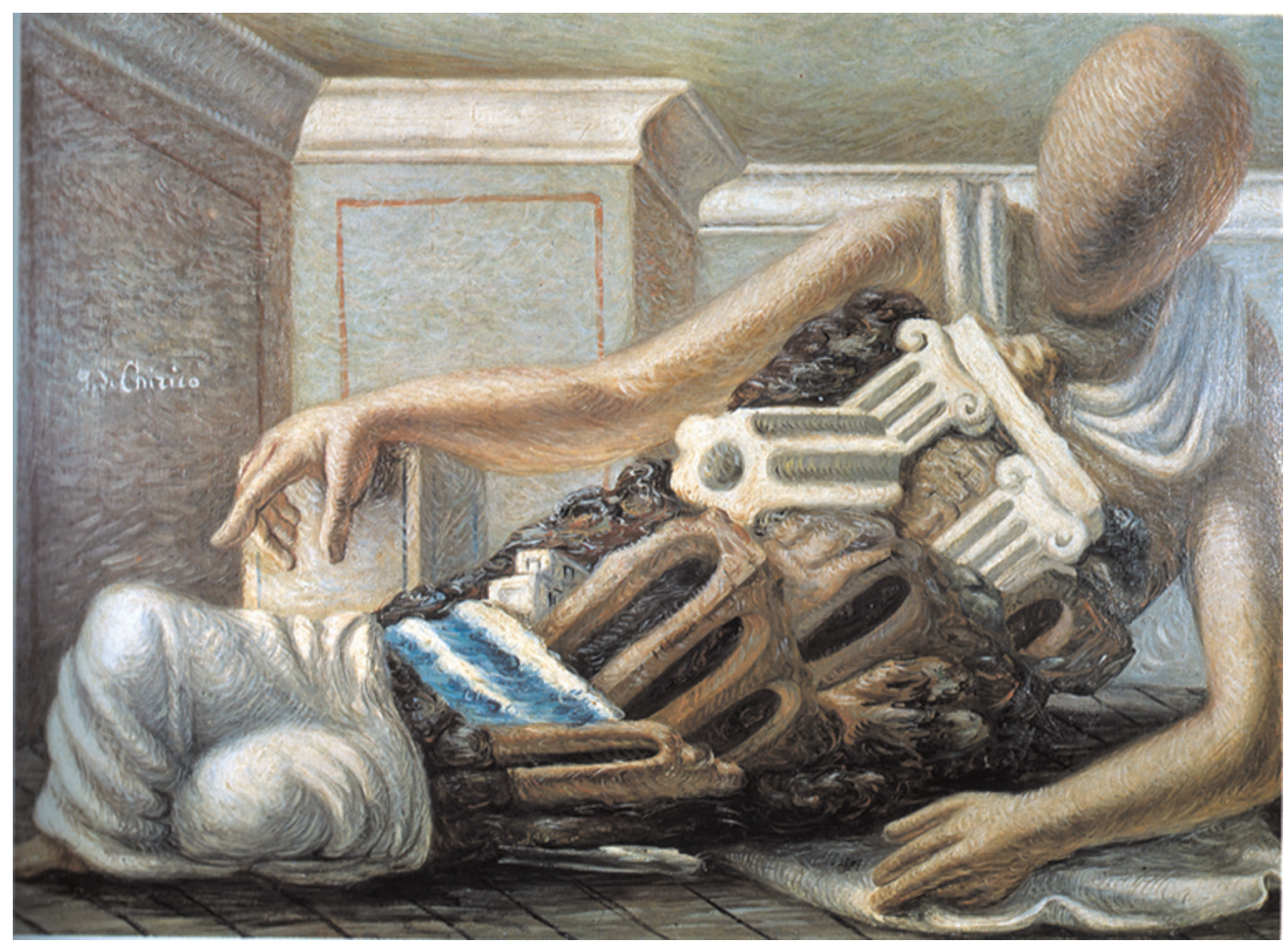

already familiar with Piranesi's work and publications before 1920, and that this underpins his very interest in the 1920 exhibition.

\section{On the importance of the arcade}

A series of De Chirico's statements and visual motifs assume a more precise meaning when one keeps Piranesi in mind. It is all a matter of the relative worth of Roman and Greek art and culture. The main issue in the eighteenth-century debate over the respective merits of Greek and Roman architecture lay in the way they spanned space. The Greeks used supporting pillars or columns on which they laid horizontal beams. This meant that they could span only short distances, certainly when building in stone. By contrast, the Romans understood the use of masonry, and developed the arch, the vault and the dome, which enabled them to span huge distances: a prime example is the Pantheon. To Piranesi, the greatness of Roman architecture lay in the 
engineering work and especially in the development of the vault and the arcade or gallery. ${ }^{39}$

And it was again the arcade that was at the heart of De Chirico's poetic vision of the city of Rome, of which he wrote in 1911/12: 'In Rome the sense of divination is much wider. It is the sensation produced by infinite greatness and distance that is captured by the Roman builders in the experience of the vault-a reflexion of the shock-like impression of infinity the starry sky can make on man. The arcade is there to stay forever [...] its beauty resides in the line: the enigma of fatality'; 'There is nothing like the enigma of the Arcade-which the Romans invented. A street, an arch: the sun looks different when it bathes a Roman wall in light. And there is something about it more mysteriously plaintive than in French architecture, and less ferocious too. The Roman arcade is a fatality. Its voice speaks in riddles filled with a strangely Roman poetry, of shadows on old walls and a curious Music ... ${ }^{40}$ It seems highly unlikely that De Chirico has chosen this motif purely on the basis of his own first impressions of the city. He most probably formed his own 'Roman myth' at a much earlier stage, with Piranesi at the back of his mind.

The probability that in Munich, or later, De Chirico read Piranesi's works with his brother, Andrea, adds extra support to the presupposition that he developed his pittura metafisica partly on the basis of trophy iconography. This iconography is, after all, a distinct presence in Piranesi's œuvre, even as far as the titles of his publications. One of Piranesi's first archaeological publications was devoted entirely to the Trophies of Marius (Trofei di Ottaviano Augusto, 1753) and he drew these two sculptures again and again. ${ }^{41}$ Piranesi's prints, even more than the dry drawings by Reinach, definitely create the monumental impression that De Chirico gave his grande metafisico. In addition, in 1774-75 Piranesi devoted a separate publication to Hadrian's triumphal column, the Trofeo o sia Magnifica Colonna Coclide di marmo. The decoration of this famous 'magnificent spiral column', which Piranesi also calls a 'trophy', includes some very well-known depictions of primitive trophies. These may well have been a source of inspiration for De Chirico. ${ }^{42}$

In addition to the depiction of the trophy and the 'doll', Piranesi mainly helps us place the motif of the archeologi in a new light. From the mid-1920s De Chirico developed the motif of the sitting, or halfoutstretched, manichini who have in their laps a trophy-like heap of fragments of classical ruins. Towards the end of his life he also had some of these figures cast in bronze. The archeologi are not burdened by the past, but carry it with them or protect it. The rubble in their laps at first sight seems quite a jumble; however, De Chirico deliberately and quite clearly plays Greek and Roman symbols off against one another. The 'Greek' elements are the front of the temple and the bits of column and sometimes, even more explicitly, two columns with a simple load-bearing beam that demonstrate the elementary Greek building principle. The 'Roman' elements are the arch, the arcade, the fountain and the heavy supporting wall. When the archeologo is alone, he invariably carries both Greek and Roman fragments: the front of a temple and an arch, for example; when the archeologi make a couple, the classic heritage is sometimes clearly divided. 
In a whole series of paintings and drawings, in the bronze sculptures, but also in his set for the 1929 dance production Le Bal, De Chirico simplifies this into an obvious contrast. For instance, the dance set has the Greek temple on a rock on the right and the Roman arch on the left. Sometimes it is as if De Chirico has swept together all the rubble from one of Piranesi's archaeological prints into the archaeologists' laps, and is thus quoting him quite literally. ${ }^{43}$ In this manner he, several times, pasted the cyclopic foundations of the Mausoleum of Hadrian from the Antichità into the archeologi's pile of ruins. ${ }^{44}$ De Chirico's archeologi do not, consequently, refer loosely to antiquity in general, but to a specific story. To De Chirico, who was born in Volos, where the voyage of the Argonauts began, but who was Italian by choice, the culture of antiquity was not a unified whole, but a duality and a tension that he carried inside his life.

Piranesi is essential to De Chirico's overall vision of Rome and antiquity, and probably to his artistic strategy as a whole. Piranesi was, after all, an artist who realised and glorified the grandeur of antiquity, but who was at the same time aware that the past is a raw material and not a model. In this way he was as an artist able to claim the superb freedom to make something greater than the past, and so, create his own 'Rome': his personal poetic world. This description comes much closer to De Chirico's artistic project than the interpretation that presents him as a hero of modern life. In the one page De Chirico wrote about Piranesi, a striking characterisation of his own pittura metafisica shines through: 'his images are permeated with fantasy, often with caprice, with romantic musing ... Piran- esi's etchings sometimes create a fantastic and ghostly impression and an astonishingly rich overall impression; his etchings are so full of chiaroscuro and effects that they appear almost garishly coloured.' And it was De Chirico's opinion that, compared to the art being produced in 1920, Piranesi's work was 'unsurpassable' and 'astounding'. ${ }^{45}$ De Chirico spent the last decades of his life near the Spanish Steps in Rome. There are indications that during this period he still went regularly to work at the print collection of the Calcografia Nazionale near the Trevi Fountain, which was within walking distance of his flat. ${ }^{46}$ The Calcografia holds not only a large collection of Piranesi's etchings, but also cherishes as one of its greatest treasures the complete collection of his copper plates, copies from which were still being printed as late as the twentieth century. Piranesi was so close and so important to De Chirico that, again, he had to withhold him out of sheer self-preservation, to make room for his own work.

An artistic œuvre has to free itself from the place where it arose, and appear independent and new, in order to be 'disseminated' - to invite new interpretations and to be misunderstood — and to accomplish something in the world. When, however, the misunderstandings after a time have petrified into clichés, they need to be reread in the counter-direction. A meticulous historical recontextualisation may yield elements that can, once again, make living material from an œuvre that is imprisoned in a standardised view or an established reputation: so the art work may appear again as a complex human document, interwoven with history and society, giving an indication of the human condition. In this instance the 
new interpretation does not unmask the work of art, but figures out how something can be remembered and passed on. A few of De Chirico's works have become key images of the twentieth century. This is precisely why it is important to reverse the stereotypes and to realise that De Chirico was, in spite of all this, not even half a hero of modernity. His entire œuvre - not only the late work but also the pittura metafisica-is about the reworking and assimilation of some chunks from the great mass of images, stories and meanings that have accumulated around the Mediterranean Sea, in order both to preserve and to overcome them by making artistic images from them. It is probably precisely because the pittura metafisica does not express modernity that it appeals to a modern intellect. De Chirico is modern, not like Marinetti or Picasso, but like Géricault and Kiefer.

\section{Notes and references}

1. This article is a revised and significantly abridged version of an article originally entitled 'Geen glorie zonder tragiek! Over de trofeefiguur in het œuvre van Giorgio De Chirico (en Piranesi)', De Witte Raaf, 132 (2008), pp. 5-12. Translated from the Dutch by Gregory Ball.

2. G. Apollinaire, 'Les sensations très aigues et très modernes de M. De Chirico prennent d'ordinaire une forme architecturale.' Apollinaire's review appeared in

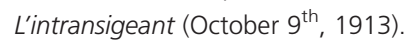

3. André Breton: 'J'ai mis, nous avons mis cinq ans à désespérer de Chirico et à admettre qu'il eût perdu tout sense de ce qu'il faisait. ... Si cet homme avait eu quelque courage il y a longtemps qu'il se serait lassé de ce jeu qui consiste à bafouer son génie perdu.': A. Breton, 'Fuvres récentes de Chirico à la
Galerie de l'Effort Moderne', L'art vivant, 77 (March $\left.1^{\text {st }}, 1928\right)$, p. 189; published in the dossier 'Giorgio de Chirico et les surrealistes', in, J. Clair, W. Rubin and W. Schmied, eds, Giorgio de Chirico, exh. cat. (Munich, Prestel; Paris, Centre Pompidou, 1982-83), p. 261.

4. 'Chirico a réalisé ce prodige de peindre des "paysages nouveaux" ... et en 1918, tout est fini.': P. Eluard, 'Premières vues anciennes', in, Clair, Rubin and Schmied, eds, Giorgio de Chirico, op. cit., pp. 264-265.

5. P. Baldacci, Giorgio de Chirico: The Metaphysical Period, 1888-1919 (Boston, Bulfinch Press, 1997), p. 151: 'this desire to situate even just the Parisian works within the spirit and practice of modernism-a spirit and practice which, supposedly accepted as first, would later be rejected-is against all evidence. ... we must recognize his fundamental foreignness to the values of orthodox modernism, of which metaphysical art is the alter-ego, sharing its aspirations but ideologically opposed.'

6. De Chirico was writing in German in 1912; quoted in Baldacci, Giorgio de Chirico, op. cit., pp. 67, 70. (My translation.)

7. Vale Lutetia (February, 1925), included in Maurizio Fagiolo dell'Arco and Paolo Baldacci, Giorgio de Chirico. Parigi 1924-1929. Dalla nascita del Surrealismo al crollo di Wall Street (Milan, Ph. Daverio, 1982), pp. 586-589.

8. Baldacci, Giorgio de Chirico, op. cit., pp. 7-8.

9. 'La culture initiale de De Chirico est philosophique plus que picturale': Maurizio Fagiolo dell'Arco in Clair, Rubin and Schmied, eds, Giorgio de Chirico, op. cit., p. 63.

10. De Chirico reused and varied this image under several other titles, including Le grand automate.

11. R. Longhi, 'Il dio ortopedico', /l Tempo (1919); Baldacci presents the full article in Giorgio de Chirico, op. cit., pp. 409-411. 
12. See M. Steinhauser, "'Die Anatomie Selbdritt". Das Bild des zergliederten Körpers zwischen Wissenschaft und Kunst', in, P. Müller-Tamm and K. Sykora, eds, Puppen, Körper, Automaten, Phantasmen der Moderne, exh. cat. (Dusseldorf and Cologne, Kunstsammlung Nordrhein-Westfalen/Oktagon, 1999), pp. 106-124. De Chirico's doll is a 'Zeichen der modernen Kontingenzerfahrung', etc.; De Chirico's Liebe zur Geometrie is, she believes, apparent in the erratically assembled grandi metafisici (p. 123).

13. W. Bohn, Apollinaire and the Faceless Man: The Creation and Evolution of a Modern Motif (London and Toronto, Associated University Press, 1991). In 1913, in the poem entitled Le musician de Saint-Merry, Apollinaire introduced a flute-player 'with no ears, eyes or nose'. In 1913, Savinio himself wrote a lyrical drama called Les chants de la mi-mort, in which a 'man without a face' also appears. And Savinio is said to have done some sketches of this figure. Might De Chirico have seen them? Savinio also used sidonieshalf-solid papier-maché dolls used to display wigs-in his musical drama Le Général et la sidoni, and De Chirico himself referred to these dolls. Baldacci, Giorgio de Chirico, op. cit., p. 260. In 1942, under the name of his second wife, Isabella Far, De Chirico gave a late interpretation of the 'manichino' as an 'unheimliche' figure which, as a lifeless object, aspires to be human and thereby becomes 'monstruoso': 'll teatro spettacolo', in, Giorgio De Chirico and Isabella Far, Commedia dell'arte moderna, ed., J. de Sanna (Rome, Abscondita, 2002), pp. 204212.

14. See Paolo Baldacci and Gerd Roos, De Chirico, exh. cat., Palazzo Zabarella, Padua (Venice, Marsilio Editori, 2007), pp. 18-23, the chapter entitled 'Il manichino, dal "Golem" al "Trovatore"'. See also Baldacci, Giorgio de Chirico, op. cit., pp. 165-166: 'The manne- quin derives from one of Apollinaire's poetic personages (though only after having been subjected to a series of iconographic transformations and symbolic overlaps, first by Savinio and later by De Chirico).'

15. Baldacci, Giorgio de Chirico, op. cit., p. 261.

16. See also G. Picard, Les Trophées Romains. Contribution à l'histoire de la Religion et de l'art triumphal de Rome (Paris, Ed. De Boccard, 1957). In the first chapter, Picard outlines the Greek background to the trophy figure. See also A. J. Janssen, Het antieke tropaion (Lederberg and Ghent, Drukkeij Erasmus, 1957).

17. Regarding these works, entitled 'Trophée', see Fagiolo dell'Arco and Baldacci, Giorgio de Chirico, cat. nos. 34 and 69-73 (all from 1926)

18. Giorgio De Chirico, Hebdomeros (1929; Amsterdam, Meulenhoff, Amsterdam, 1973), pp. 51-52.

19. Fagiolo dell'Arco and Baldacci, Giorgio de Chirico, op. cit., p. 77

20. Baldacci and Roos, De Chirico, op. cit., cat. no. 69.

21. Fagiolo dell'Arco and Baldacci, Giorgio de Chirico, op. cit., cat. no. 247

22. Ibid., cat. no. 216: Le Triomphe; the Trofeo is reproduced in Giorgio De Chirico, 1888-1978, exh. cat., Galleria Nazionale d'arte moderna, Rome, 2 vols (Rome, De Luca Editore, 1981), cat. no. 56.2.

23. In the literature on De Chirico I have only found one, indirect, passage that suggests a link between the manichini of the metaphysical period and the tradition of the trophy. In 'The Origins of Architecture, After De Chirico', Art History, 26, 1 (February, 2003), pp. 7899. Thomas Mical quotes a passage from George Hersey's The Lost Meaning of Classical Architecture (1988), which refers to De Chirico in this connection: 'trophies were originally erected at the point where the tide turned against the losers. Trophies, that is to say mannequins formed of the arms, weapons and helmets of the slain enemy, were set up to appease 
their shades and to prevent the gods from punishing the victors who had killed them. ... This rich description of these forlorn sacrificial figures, echoed in De Chirico's images of the mannequin ...'.

24. Roos on Reinach, in G. Roos, Giorgio De Chirico, München, 1906-1909, exh. cat. (Munich, Akademie der Bildenden Künste, 1994), pp. $377 f f$.

25. S. Reinach, Répertoire de la Statuaire Grecque et Romaine, 6 vols (Paris, Editions Ernest Leroux, from 1897); Répertoire de Reliefs Grecs et Romains, 3 vols (Paris, Editions Ernest Leroux, 1909-12).

26. M. Fagiolo dell'Arco, 'De Chirico à Paris, 1911-1915', in, Clair, Rubin and Schmied, eds, Giorgio de Chirico, op. cit., p. 87: 'De Chirico et Savinio copient le manuel de Reinach jusq'au plagiat...'

27. S. Reinach, Les Ensembles, vol. 1 of Répertoire de Reliefs Grecs et Romains, op. cit., pp. 289-290.

28. At Lepcis Magna. See G. Picard, Les Trophées Romains., op. cit., plate XXXI.

29. In the same period, De Chirico also used the eye in several composizioni metafisici-Le Corsaire (1916) and Le salut d'un ami lointain (1916)_but then never again.

30. Salomon Reinach's articles were collected in Cultes, Mythes et Religions, 5 vols (Paris, Editions Ernest Leroux, 1905), and, more recently, a broad selection has been reissued in Paris by Laffont (1996). Other publications by Reinach include Orpheus, histoire générale des religions and Apollo, histoire générale des arts plastiques, which include the lectures he gave at the Ecole du Louvre in 1902-3 (Paris, Hachette, 1904).

31. S. Reinach, 'Tarpeia', Revue Archeologique (1908), pp. 48-74; included in Cultes, Mythes et Religions, vol. 2, op. cit., pp. 223-253.

32. A. Reinach, 'Les Trophées et les origines religieuses de la guerre', in Revue d'ethnographie et de sociologie, vol. 4 (1913), pp. 211-237. His article on 'Tropaeum' in the Dictionnaire des Antiquités is also very interesting (1913), pp. 497-518, and contains references to the trophy iconography on coins and reconstructions of monuments. In the same year, Reinach also published 'Les têtes coupées et les Trophées en Gaule', in La Revue Celtique.

33. For instance, Roos, Giorgio De Chirico, op. cit., p. 32; Baldacci, Giorgio de Chirico, op. cit., writes on pp. 75-76 about his first visit to the Temple of Vesta: 'it made him feel as though he were plunging into the depths of the past.' De Chirico 'took careful note of the temple as a future model for his painted towers'; 'all of the earliest metaphysical works (up to 1914-15) were born of visual notations and sketches made on the spot'. Baldacci does not, however, give any examples of sketches from 1909 that De Chirico may have used. Baldacci, Giorgio de Chirico, op. cit., p. 75: 'And it is precisely upon this strangeness, this mysterious aspect that the sites and structures of Rome had assumed for him, that he began constructing an aesthetics based on architecture, wherein architectonic forms are transmogrified into metaphors of the deepest and most complex sentiments.'

34. Roos, Giorgio De Chirico, op. cit., p. 179.

35. Ibid., p. 260

36. Reinach, Les Ensembles, La Colonne Aurélienne à Rome, op. cit.

37. 'Mostra degli artisti belgi alla Galleria Moretti'; 'Mostra Piranesi al Castello'; 'Esposizione, Sinopico Graziosi, Nizzoli alle Galleria Arte,' /l Convegno, 1, 5 (June, 1920), pp. 67-71 (signed D.C.). The review of the Mostra Piranesi is on pp. 69-70. At that time, De Chirico was commuting back and forth between Rome, Florence and Milan. The reviews are not included in De Chirico's Scritti (1918-43) published by the Fondazione Giorgio e Isa De Chirico in 2002. The nota biografica does mention that in this period De Chirico published 'indagini e meditazioni' in several periodicals, including // Convegno. The only 
place I know of where these reviews are mentioned is in the list of Scritti di de Chirico, in the second part of the catalogue of the exhibition at the Galleria Nazionale in Rome in 1981-1982, Giorgio De Chirico, 1888-1978, op. cit., p. 67.

38. Civica Raccolta delle Stampe Achille Bertarelli, Castello Sforzesco, Milan.

39. See L. Kantor-Kazovsky, Piranesi as Interpreter of Roman Architecture and the Origins of his Intellectual World (Florence, Leo S. Olschki Editore, 2006).

40. 'A Rome le sens du présage a quelque chose de plus vaste. Une sensation de grandeur infinie et de lointain donne la même sensation que le constructeur romain fixa dans le sentiment de l'arcade reflet du spasme d'infini que la couche célestielle produit quelquefois sur l'homme'; 'L'arcade est là pour toujours ... mais sa beauté est la ligne: énigme de la fatalité, symbole de la volonté intransigeante.'; 'Rien comme l'énigme de l'Arcade-créée par les Romains, de tout ce qui peut être Romain. Une rue; un arc; le soleil a une autre expression lorsqu'il baigne de lumière un mur romain; il y a quelque chose en cela de plus mysterieusement plaintif que dans I'architecture française. [...] L'Arcade romaine est une fatalité; elle a une voix qui parle en énigmes pleines d'une poésie étrangement romaine ...': from a manuscript by G. De Chirico, Le sentiment de la préhistoire (1913) and Une fête (1912); quoting from M. Fagiolo dell'Arco, 'De Chirico à Paris, 1911-1915,' op. cit., p. 84. These pieces are published in: Giorgio De Chirico, I/ meccanismo del pensiero. Critica, polemica, autobiografia 1911-1943, ed., Maurizio Fagiolo (Turin, Einaudi, 1985), a collection of published and unpublished writings: quotations on pp. 23, 35, 20. In his memoirs, De Chirico's student friend Pikionis writes that, in spring 1912, De Chirico spoke to him of Rome and the impor- tance of its architecture in the following terms: 'Latin is better able to express mystery than any other language ever. The same applies to Roman architecture. The mystery lies in Rome ...' See Roos, Giorgio De Chirico, op. cit., p. 303.

41. Giovanni Battista Piranesi, Trofei di Ottaviano Augusto (1753). Piranesi includes two large illustrations-L. Ficacci, Giovanni Battista Piranesi: The Complete Etchings (Cologne, Taschen, 2000), nos. 131 and 132-and again depicts the two trophies together on a smaller scale in a single print in Le Rovine del Castello dell'Aqua Giulia (1761): Ficacci, Piranesi, no. 431

42. Giovanni Battista Piranesi, Trofeo o sia Magnifica Colonna Coclide (1774-75). Every side of the base of the column is decorated with 'trophy heaps', depicted on a large scale: the prints are $59 \times 83 \mathrm{~cm}$ (see Ficacci, Piranesi, no. 713); one print of the triumphal parade shows two classical trophy dolls with a pile of helmets and weapons flanking a Nike (Ficacci, Piranesi, no. 718).

43. For instance, the print with the Urna di marmo... from the Antichità Romane /l (Ficacci, Piranesi, no. 234).

44. Antichità Romane IV (Ficacci, Piranesi, no. 332). See, for example, De Chirico's first etching of the Archéologes in 1929: Giorgio De Chirico, 1888-1978, op. cit., cat. no. 67.

45. G. De Chirico [D.C.], 'Mostra Piranesi al Castello,' op. cit., pp. 69-70.

46. See what Gerard Tempest has to say about De Chirico's visits and his use of prints and etchings at the 'Stamperia Nazionale' in his 2001 interview with Michael Taylor in Giorgio De Chirico and the Myth of Ariadne (London, Merrell, 2002), pp. 176-186, esp. 180. Tempest knew De Chirico in Rome in 1948-9. 